\title{
Penggunaan Media Puzzle secara Daring terhadap Hasil Belajar IPA Kelas V SD
}

\section{Agisna Najiah Maulidah ${ }^{*}$, Aslam ${ }^{2}$}

1,2 Program Studi Pendidikan Guru Sekolah Dasar, Universitas Muhammadiyah Prof. Dr. Hamka, Jakarta, Indonesia

\section{ART I CLE I N F O}

Article history:

Received March 09, 2021

Revised April 15, 2021

Accepted April 30, 2021

Available online August 25, 2021

Kata Kunci:

Media Puzzle, Hasil Belajar, IPA

Keywords:

Media Puzzle, Learning

Outcomes, Scince

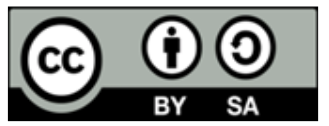

This is an open access article under the CC BY-SA license.

Copyright (@) 2021 by Author. Published by Universitas Pendidikan Ganesha.

\begin{abstract}
A B S T R A K
Rendahnya hasil belajar siswa dalam proses pembelajaran pada pelajaran IPA akibat pandemi COVID-19. Penelitian ini bertujuan untuk menganalisis penggunaan media puzzle dalam pembelajaran secara daring terhadap hasil belajar siswa sekolah dasar. Subjek penelitian ini adalah siswa kelas $\mathrm{V}$. Metode penelitian yang digunakan yaitu penelitian eksperimen dengan desain penelitian yaitu Quasi Experimental design. Jumlah sampel yang diteliti sebanyak 60 siswa dibagi menjadi 2 kelompok, yaitu 30 siswa sebagai kelas kontrol dan 30 siswa sebagai kelas eksperimen, dengan teknik pengambilan sampel yang digunakan adalah sampling jenuh. Instrumen yang digunakan dalam penelitian ini adalah tes hasil belajar berbentuk pilihan ganda yang telah divalidasi oleh dosen ahli dengan menggunakan Produck Moment. Uji reliabilitas menggunakan Cronbach's Alpha. Uji normalitas dan uji homogenitas menggunakan uji Kolmogorov-Smirnov dengan SPSS. Hasil pengujian hipotesis menggunakan uji Independent Samples $T$ Test diperoleh sebesar $0,000<0,05$ maka Ho diterima dan Ha di tolak. Hal ini berarti bahwa ada pengaruh yang signifikan terhadap hasil belajar IImu Pengetahuan Alam (IPA) dengan menggunakan media puzzle pada siswa SD. Media puzzle bisa digunakan sebagai variasi model pembelajaran yang dapat membuat siswa tidak jenuh dan merasa senang mengikuti pembelajaran IPA, sehingga materi yang disampaikan dapat diserap dengan baik dan hasil belajar siswa di atas kriteria ketuntasan minimal yang sudah ditentukan.
\end{abstract}

\section{A BS TRACT}

The low learning outcomes of students in the learning process on the content of science lessons due to the COVID-19 pandemic. This study aims to determine the effect of Puzzle media in distance learning on the learning outcomes of elementary school students. The subjects of this study were students of class $V$. The research method used was experimental research with a research design that was Quasi-Experimental design. The number of samples studied was 60 students divided into 2 groups, namely 30 students as the control class and 30 students as the experimental class, with the sampling technique used was saturated sampling. The instrument used in this study is a multiplechoice learning outcome test that has been validated by expert lecturers using the Product Moment, while the reliability test uses Cronbach's Alpha, for the next calculation, the normality test, and the homogeneity test uses the Kolmogorov-Smirnov test with SPSS. The results of hypothesis testing using the Independent Samples T-Test were obtained at $0.000<0.05$, then Ho was accepted and Ha was rejected. This means that there is a significant effect on learning outcomes of Natural Sciences (IPA) using Puzzle media for elementary students.

\section{PENDAHULUAN}

Pendidikan merupakan salah satu sarana untuk membentuk karakter dalam memahami tentang suatu pembelajaran. Siswa diharapkan mengerti dan dapat memahami yang diajarkan serta terdapat perubahan tingkah laku dalam aktivitas yang dilaksanakan atas dasar pengetahuan (Pertiwi et al., 2019; Raibowo et al., 2019). Pendidik menjadi fasilitator dalam membantu siswa untuk mengembangkan potensi yang didasarkan pada pengembangan karakter yang baik (Anindita et al., 2018; Berliana et al., 2018). Salah satu kegiatan pendidikan adalah pembelajaran. Pembelajaran merupakan sistem yang berupa gabungan dari beberapa komponen yang berhubungan untuk mencapai tujuan pembelajaran (Renda \& Jampel, 2013; Yektyastuti \& Ikhsan, 2016). Salah satu pembelajaran yang paling kompleks 
adalah pembelajaran tematik. Dalam pembelajaran tematik terdapat beberapa muatan yang salah satunya adalah pembelajaran IPA. IPA ialah materi yang berkaitan dengan mengenali tentang alam sekitar. IPA tidak hanya ilmu yang berbentuk sistematis, melainkan pula sesuatu proses temuan ilmiah. Pembelajaran IPA di sekolah dasar diharapkan menjadi wahana untuk partisipan didik buat menekuni dalam kehidupan sehari-hari (Kusumawati, 2016; Widiyatmoko, 2014). Dalam pendidikan IPA, tujuan pada mata pelajaran IPA menjadi penanda keberhasilan pendidikan. Pendidikan tidak hanya sukses apabila seseorang pendidik tidak mengenali tujuan pendidikan. Oleh karena itu, sebaiknya guru betul- betul menguasai esensi tujuan pendidikan. Tujuan pendidikan IPA mencerminkan tindakan- tindakan yang harus dilakukan agar keterampilan- keterampilan serta kecakapan- kecakapan yang diharapkan bisa dicapai oleh siswa (Putra, 2017; Sudjana \& Rivai, 2011). Pendidikan IPA sangat berpengaruh terhadap potensi siswa sejak dini karena sangat penting dalam tahapan selanjutnya di sekolah dasar. Bila potensi siswa pada saat pendidikan IPA di SD rendah, maka sangat berpengaruh dalam mamahami pengetahuan IPA (Sri Wahyuni, 2006; Widiana, 2016).

Permasalahan yang terjadi saat ini yaitu banyak siswa yang tidak memahami materi pembelajaran yang disebabkan oleh kurangnya media pembelajaran yang memfasilitasi siswa dalam belajar (Agustini et al., 2021; Kharizma Kintan Permata1 \& Lidinillah, 2017). Kurangnya media pembelajaran ini berdampak pada pemahaman materi pembelajaran yang rendah (Herayanti et al., 2017; Maqfiroh et al., 2020; Puspitorini et al., 2014). Masih banyak guru yang tidak menggunakan media dalam melaksanakan pembelajaran. Media pendidikan ialah fasilitas untuk mempermudah dalam proses pembelajaran.

Berdasarkan hasil observasi di SDN Telaga Murni 03 diketahui bahwa nilai IPA kelas V rendah. Peserta didik pada awal susahnya menguasai materi pelajaran. Media pendidikan yang digunakan guru kurang menarik. Siswa di sekolah dasar rata-rata menggunakan handphone untuk mengkuti pembelajaran dalam jaringan. Awalnya penggunaan media elektronik tersebut mendapatkan respon yang baik pada beberapa siswa, meskipun ada beberapa kendala yang dialami, baik oleh guru, siswa, maupun orang tua siswa. Namun, setelah pembelajaran berjalan lebih lama ditemukan masalah baru, yaitu siswa menjadi bosan karena mereka hanya menonton dan membaca materi pembelajaran tanpa banyak interaksi yang terjadi saat belajar. Di samping itu, siswa sudah mulai bosan dengan media yang digunakan. Hal tersebut mengakibatkan tujuan pembelajaran tidak tercapai, salah satu di antaranya adalah pada muatan pelajaran IPA.

Adanya kesenjangan antara kondisi nyata dan kondisi yang diharapkan perlu dicarikan solusinya. Jika permasalahan tersebut dibiarkan dapat berdampak terhadap hasil belajar siswa. Salah satu solusi yang dapat diberikan yaitu dengan menggunakan media pembelajaran yang sesuai dengan pembelajaran saat ini. Media pembelajaran dapat mempermudah siswa dalam menerima materi yang diajarkan oleh guru (Andriyani \& Suniasih, 2021; Audia et al., 2020; Habibi \& Setyaningtyas, 2021). Media pembelajaran yang meliputi audio, visual, dan gabungan antara keduanya untuk memudahkan partisipan didik dalam menguasai sesuatu modul pendidikan yang di dalamnya terdapat aktivitas stimulus reaksi antara pendidik serta partisipan didik (Puspitasari \& Murda, 2018; Putri et al., 2020; Wahyuni, 2018). Peranan penting media dalam kegiatan belajar mengajar yaitu media pendidikan dapat meningkatkan hasil belajar dan siswa termotivasi berinteraksi secara langsung dengan guru, lingkungan, masyarakat sehingga meningkatkan atensi dalam kehidupan sehari-hari serta bisa menanggulangi keterbatasan waktu dan ruang (Karo-Karo \& Rohani, 2018; Nurseto, 2011). Media pendidikan yang digunakan berupa media puzzle. Kareana adanya wabah Covid- 19 menyerang dunia, aktivitas belajar bisa dilaksanakan secara online tanpa tatap muka di sekolah. Sekolah memakai aplikasi Zoom Meeting serta WA buat memudahkan berbagi audio visual. Dalam penelitian ini digunakan media puzzle. Dengan menggunakan media puzzle dapat mempermudah siswa mengikuti pembelajaran sesuai dengan materi ajar.

Puzzle merupakan wujud game dalam misteri yang berisi pengetahuan serta keahlian yang bertabiat akademik serta memiliki faktor pelatihan dengan tujuan untuk memberikan peluang kepada siswa melaksanakan aplikasi serta latihan yang dirancang dalam wujud game (Berliana et al., 2018; Elan et al., 2017; Zulfa et al., 2020). Media ini bisa menarik atensi siswa lebih kreatif dalam proses berpikir (Kharizma Kintan Permata1 \& Lidinillah, 2017; Syafitri et al., 2019). Puzzle sejenis game yang berbentuk metode bermainnya ialah dengan menyusunnya sehingga gambar tersusun lengkap dengan tujuan dapat meningkatkan keahlian kognitif serta dapat memecahkan permasalahan bersama teman sekelompok (Nurul Husna1 \& Halim, 2017). Secara otomatis siswa dapat tertarik untuk mengamati media puzzle. Temuan sebelumnya menyatakan media puzzle mempunyai pengaruh yang signifikan terhadap hasil belajar siswa (Widya Hastuti, 2017). Media puzzle memberikan hasil yang positif terhadap peningkatan hasil belajar siswa serta lebih efisien (Bahar \& Risnawati, 2017). Menggunakan salah satu media membuat hasil belajar partisipan siswa meningkat ialah memakai media puzzle. (Syafitri et al., 2019). Media puzzle ialah suatu media pendidikan yang melatih proses berpikir siswa menjadi lebih kreatif serta menjadi daya 
tarik siswa dalam kegiatan belajar mengajar (Kristiana et al., 2017). Penelitian ini bertujuan untuk menganalisis penggunaan media puzzle dalam pembelajaran secara daring terhadap hasil belajar siswa sekolah dasar.

\section{METODE}

Penelitian ini termasuk metode kuantitatif deskriptif, yaitu metode eksperimen semu. Metode ini adalah yang pertama untuk menentukan bahwa dua kelas diberikan materi yang sama tetapi ditangani dengan cara yang berbeda. Populasi dalam penelitian ini adalah seluruh siswa kelas VA dan VB SDN Telaga Murni 03 yang terdaftar pada tahun ajaran 2020/2021. Ada 60 orang siswa, yang terdiri atas 30 orang siswa di kelas VA dan 30 orang siswa di kelas VB. Teknik sampling yang digunakan dalam penelitian ini adalah nonprobability sampling. Nonprobability sampling adalah teknik pengambilan sampel yang tidak memberi peluang/kesempatan sama bagi setiap unsur atau anggota populasi untuk dipilih menjadi sampel. Variabel penelitian terdapat variabel bebas dan terikat. Kelas VA sebagai kelas kontrol diberikan materi siklus air dan menggunakan media pembelajaran yang biasa digunakan guru, sedangkan untuk kelas VB sebagai kelas eksperimen diberikan materi siklus air dengan menggunakan media puzzle. Populasi yaitu suatu wilayah yang terdiri dari objek dengan jumlah dan beberapa fitur yang akan dipelajari (Sugiyono, 2014). Teknik pengumpulan data menggunakan wawancara, dokumentasi, tes, dan angket. Media puzzle adalah variabel bebas, sedangkan hasil belajar siswa termasuk variabel terikat. Teknik analisis data menggunakan rumus uji t yang sebelumnya dipastikan data sudah berdistribusi Normal dan homogen.

\section{HASIL DAN PEMBAHASAN}

Hasil

Untuk memberikan informasi tentang sebaran data masing-masing kelas maka dihitung mean, median, modus, dan standar deviasi seperti dalam Tabel 1.

Tabel 1. Deskripsi Data Hasil Belajar

\begin{tabular}{lcccccc}
\hline \multicolumn{1}{c}{ Kelas } & Mean & Median & Modus & $\begin{array}{c}\text { Std. } \\
\text { Deviasi }\end{array}$ & $\begin{array}{c}\text { Nilai } \\
\text { Tertinggi }\end{array}$ & $\begin{array}{c}\text { Nilai } \\
\text { Terendah }\end{array}$ \\
\hline Post-test Kontrol (VA) & 76,87 & 77,00 & 67 & 5,812 & 89 & 67 \\
Post-test Eksperimen (VB) & 85,47 & 85,00 & 85 & 3,711 & 95 & 80 \\
\hline
\end{tabular}

Berdasarkan data tersebut terdapat perbedaan nilai di tahap awal dan akhir kedua kelas. Dengan demikian, dapat dikatakan bahwa kemampuan awal siswa kelas eksperimen sebelum diberikannya perlakuan dengan menggunakan media puzzle cukup rendah. Setelah kegiatan pembelajaran menggunakan media puzzle, siswa dalam kelas eksperimen mendapatkan nilai pengetahuan yang lebih unggul dibanding kelas kontrol dengan jumlah rata- rata sebesar 85, 47. Nilai kelas eksperimen yang mengalami peningkatan memperlihatkan bahwa siswa lebih tertarik serta termotivasi dengan memakai media puzzle. Uji normalitas merupakan suatu cara untuk mencari tahu hasil perkembangan kognitif Ilmu Pengetahuan Alam. Siswa yang memakai media puzzle berdistribusi normal atau sebaliknya, penghitungan ini dilakukan melalui uji normalitas dengan ketetapan yang signifikan $(\alpha=0,05)$. Hasilnya dapat diperhatikan dalam tabel.

Tabel 2. Uji Normalitas Data Hasil Belajar

\begin{tabular}{|c|c|c|c|c|}
\hline \multirow{4}{*}{$\begin{array}{c}\text { Hasil } \\
\text { Belajar }\end{array}$} & \multirow{2}{*}{ Kelas } & \multicolumn{3}{|c|}{ Kolmogorov-Smirnova } \\
\hline & & Statistic & df & Sig. \\
\hline & Post-Test Kontrol (VA) & 0,107 & 30 & 0,200 \\
\hline & Post-Test Eksperimen (VB) & 0,117 & 30 & 0,200 \\
\hline
\end{tabular}

Berdasarkan data tersebut, hasil uji normalitas dapat dianalisis dengan membandingkan nilai (sig) terbesar dengan tingkat signifikan $(\alpha=0,05)$. Bila nilai $(\operatorname{sig})>(\alpha=0,05)$ berhak diketahui data tersebut berdistribusi normal. Dapat ditemukan nilai (sig) kelas eskperimen serta nilai (sig) kelas kontrol memiliki nilai yang tinggi dari 0,05. Didapati hasil dalam kedua kelas berdistribusi normal. Penghitungan uji homogenitas taraf signifikan $\alpha=0,05$. Dalam tipe pengujian berikut bila nilai (sig) lebih unggul dibandingkan tingkat signifikan $(0,05)$ karenanya data tersebut disimpullkan homogen. 
Tabel 3. Uji Homogenitas Data Hasil Belajar

\begin{tabular}{ccccccc}
\hline \multirow{2}{*}{ Hasil } & & Levene Statistic & df1 & df2 & Sig. \\
\cline { 2 - 6 } Belajar & Based on Mean & 3,179 & 1 & 58 & 0,080 \\
& Based on Median & 3,248 & 1 & 58 & 0,077 \\
\hline
\end{tabular}

Berdasarkan data tersebut, hasil penghitungan pada kedua kelas menyatakan bahwa (sig) 0,080 > 0,05. Ini berarti bahwa data tersebut bersifat homogen. Jika hasil pada tabel 3 bernilai (sig) $<0,05$ hasil data tersebut tidak homogen. Uji Independent samples t test difungsikan sebagai penguji perbandingan kenaikan nilai Post-test kelas diberikan treatment Media Puzzle dan non-treatment.

Tabel 4. Uji Independent Samples T Test

\begin{tabular}{|c|c|c|c|c|c|}
\hline Kelas & Mean & Std. Deviasi & $\mathbf{t}$ & df & $\begin{array}{l}\text { Sig. Two- } \\
\text { Slided p }\end{array}$ \\
\hline Post-test Kontrol (VA) & 8,600 & 1,259 & 6,831 & 58 & 0,000 \\
\hline Post-test Eksperimen (VB) & 8,600 & 1,259 & 6,831 & 49 & 0,000 \\
\hline
\end{tabular}

Berdasarkan data tersebut diperoleh nilai Sig. two-sided p disebesar 0,000<0,05, hingga bisa disimpulkan terdapat perbandingan rata- rata hasil belajar siswa kelas kontrol dengan kelas eksperimen, sehingga Ho ditolak serta Ha diterima. Ini berarti bahwa ada perbandingan yang bermakna antara nilai posttest kelas kontrol serta kelas eksperimen. Aspek yang memengaruhi keberhasilan dalam aktivitas belajar mengajar di kelas ialah dengan memakai media puzzle. Siswa menjadi lebih aktif dalam belajar. Keaktifan siswa dalam pembelajaran membuat siswa lebih termotivasi untuk belajar lebih giat. Berdasarkan uraian di atas dapat diketahui bahwa pembelajaran dengan menggunakan media puzzle secara daring efektif terhadap hasil belajar siswa. Hasil penelitian menunjukkan bahwa penggunaan media puzzle juga membantu guru dalam mengelola kelas selama pembelajaran daring berlangsung. Dengan media puzzle, siswa lebih tertarik, merasa senang, serta aktif selama proses pembelajaran. Hal ini menunjukkan bahwa media puzzle efektif digunakan untuk meningkatkan hasil belajar siswa kelas $\mathrm{V}$, khususnya pada mata pelajaran IPA materi siklus air. Selain itu, hasil nilai Posttest menunjukkan bahwa hasil belajar siswa meningkat jikan dibandingkan dengan hasil pretest.

Hasil belajar siswa meningkat karena adanya penggunaan sarana pembelajaran berupa media pembelajaran. Media pembelajaran yaitu sarana untuk memastikan keberhasilan suatu pendidikan (Iwan Falahudin, 2014; Yektyastuti \& Ikhsan, 2016). Salah satunya adalah media puzzle yang dirancang semenarik mungkin yang membuat siswa ingin memperhatikan dan memiliki semangat belajar. Media puzzle sama seperti media visual yaitu berbentuk gambar. Puzzle merupakan game yang terdiri dari potongan gambar- gambar, kotak- kotak, huruf- huruf ataupun angka- angka yang disusun semacam dalam suatu game yang kesimpulannya membentuk kosa kata, sehingga membuat partisipan didik jadi termotivasi buat menuntaskan puzzle secara pas serta kilat (Situmorang, 2012). Berdasarkan hasil posttest, kelas VA yang belajar dengan media yang biasa digunakan oleh guru membuat siswa merasa jenuh, sehingga hasil belajar siswa menjadi rendah. Berbeda halnya dengan siswa Kelas VB. Hasil belajar siswa kelas VB mengalami peningkatan. Mereka belajar dengan menggunakan media Puzzle. Siswa tersebut belajar dengan penuh percaya diri.

Pemakaian media pembelajaran dapat membangkitkan keinginan dan minat yang baru, membangkitkan motivasi dan rangsangan kegiatan belajar, dan bahkan membawa pengaruh-pengaruh psikologis terhadap siswa (Kurnia \& Damayani, 2019). Kekuatan puzzle untuk memengaruhi pikiran siswa terletak pada keseriusan dan ketelitian siswa merangkai puzzle untuk membentuk beberapa bangun datar. Media puzzle memudahkan siswa untuk memahami uraian yang dimaksudkan oleh guru ketika menyampaiakan materi pembelajaran. Siswa cepat tanggap atas materi yang disampaikan karena diiringi dengan gambar-gambar. Siswa lebih berkonsentrasi dan merasa asyik karena tugas yang diberikan oleh guru berkaitan dengan permainan mereka sehari-sehari. Menarik bagi siswa dikarenakan melalui visual dalam bentuk bangun datar nyata, sehingga siswa lebih aktif dan hasil belajar semakin meningkat.

Hasil penelitian ini memperkuat hasil penelitian sebelumnya yang menyatakan penggunaan media puzzle dapat memberikan rangsangan terhadap siswa sehingga bisa meningkatkan hasil belajar siswa (Nurul Husna1 \& Halim, 2017). Terjadinya perbedaan hasil belajar menjadi meningkat dengan menggunakan media puzzle (Anindita et al., 2018). Pembelajaran dengan media teka-teki meningkatkan pemahaman IPA siswa (Purwantoko, Susilo, 2010). Penerapan media puzzle dengan menggunakan model pembelajaran dapat meningkatkan hasil belajar siswa (Widayanti et al., 2020). Selain dapat meningkatkan hasil belajar, penggunaan media puzzle dapat meningkatkan motivasi siswa selama mengikuti 
pembelajaran (Berliana et al., 2018). Di samping keberhasilan, masih ada keterbatasan paling utama pada kasus pada pemakaian media puzzle, yaitu guru wajib bersabar dalam melaksanakan pembelajaran, sehingga memperoleh hasil yang lebih baik.

\section{SIMPULAN}

Penggunaan media puzzle secara daring efektif digunakan sehingga memengaruhi hasil belajar IPA siswa kelas V SDN Telaga Murni 03. Hal ini dapat dilihat dari hasil nilai posttest yang mengalami peningkatan. Artinya, pembelajaran menggunakan media puzzle pada siswa SD Negeri Telaga Murni 03 efektif untuk mencapai ketuntasan hasil belajar dibandingkan dengan pembelajaran hanya dengan metode ceramah. Direkomendasikan selain menggunakan media puzzle bisa digunakan sebagai variasi model pembelajaran yang dapat membuat siswa tidak jenuh dan merasa senang mengikuti pembelajaran IPA, sehingga materi yang disampaikan dapat diserap dengan baik dan hasil belajar siswa di atas kriteria ketuntasan minimal yang sudah ditentukan.

\section{DAFTAR PUSTAKA}

Agustini, M., Nulhakim, L., \& Hakim, Z. R. (2021). Developing A Contextual Learning-Based Audio Visual Media on Material of the Energy Source and Its Change for Four Grade Students at Elementary Schools. Jurnal Pendidikan Guru Sekolah Dasar, 10(2), 263-278. https://doi.org/10.33578/jpfkip.v10i2.8069.

Andriyani, N. L., \& Suniasih, N. W. (2021). Development of Learning Videos Based on Problem-Solving Characteristics of Animals and Their Habitats Contain in Science Subjects on 6th-Grade. Journal of Education, 5(1), 37-47. http://dx.doi.org/10.23887/jet.v5i1.32314.

Anindita, H., Nuroso, H., \& Reffiane, F. (2018). Kefektifan Model Talking Stick Berbantu Media Puzzle terhadap Hasil Belajar IPA Tema "Ekosistem" Kelas V SD. JS (JURNAL SEKOLAH), 3(1), 10-15. https: //doi.org/10.24114/js.v3i1.11622.

Audia, C., Yatri, I., Aslam, Mawani, S., \& Zulherman. (2020). Development of Smart Card Media for Elementary Students. Journal of Physics: Conference Series, 1783(1), 1. https://doi.org/10.1088/1742-6596/1783/1/012114.

Bahar, \& Risnawati. (2017). Pengaruh Penggunaan Media Puzzle terhadap Hasil Belajar Matematika Siswa Kelas III. Jurnal Penelitian Dan Penalaran, 9(4), 77-86. https: //doi.org/10.26858/publikan.v9i1.8446.

Berliana, N., Enawati, E., \& Lestari, I. (2018). Pengaruh Penggunaan Media Chemcrossworld Puzzle terhadap Motivasi dan Hasil Belajar Siswa SMP. Jurnal Pendidikan Dan Pembelajaran Khatulistiwa, 7(9), 2. https://jurnal.untan.ac.id/index.php/jpdpb/article/view/27820/75676578050.

Elan, E., Muiz L, D. A., \& Feranis, F. (2017). Penggunaan Media Puzzle untuk Meningkatkan Kemampuan Mengenal Bentuk Geometri. Jurnal Paud Agapedia, 1(1), 70. https://doi.org/10.17509/jpa.v1i1.7168.

Habibi, C. D., \& Setyaningtyas, E. W. (2021). Pengembangan Media Pop-Up Book untuk Kemampuan Pemecahan Masalah pada Pembelajaran Bangun Ruang Kubus dan Balok Kelas V SD. Jurnal Pendidikan Matematika, 05(02), 1341-1351. https://doi.org/10.31004/cendekia.v5i2.620.

Herayanti, L., Habibi, H., \& Fuaddunazmi, M. (2017). Pengembangan Media Pembelajaran Berbasis Moodle pada Matakuliah Fisika Dasar. Jurnal Cakrawala Pendidikan, 36(2), 210-219. https://doi.org/10.21831/cp.v36i2.13077.

Iwan Falahudin. (2014). Pemanfaatan Media dalam Pembelajaran. Diponegoro Medical Journal (Jurnal Kedokteran Diponegoro), 4, 108.

Karo-Karo, I. R., \& Rohani, R. (2018). Manfaat Media dalam Pembelajaran. AXIOM : Jurnal Pendidikan Dan Matematika, 7(1), 91-96. https://doi.org/10.30821/axiom.v7i1.1778.

Kharizma Kintan Permata1, R., \& Lidinillah, D. A. M. (2017). Media Puzzle Berbasis Tangram dalam Pembelajaran IPS. Indonesian Journal of Primary Education, 1(1), 67. https://doi.org/10.17509/ijpe.v1i1.7499.

Kristiana, I., Nurwahyunani, A., \& Sulistya Dewi, E. R. (2017). Pengaruh Model Pembelajaran TGT Menggunakan Media Puzzle terhadap Keaktifan dan Hasil Belajar Kognitif Siswa pada Materi Sistem Ekskresi Siswa Kelas Viii Mts N 1 Semarang. Bioma: Jurnal Ilmiah Biologi, 6(2), 78-92. https://doi.org/10.26877/bioma.v6i2.1740.

Kurnia, V. T., \& Damayani, A. T. (2019). Keefektifan Model Pembelajaran Number Head Together ( NHT ) Berbantu Media Puzzle terhadap Hasil Belajar Matematika. Jurnal Ilmiah Sekolah Dasar, 3(2), 192-201. https://doi.org/10.23887/jisd.v3i2.17772. 
Kusumawati, N. (2016). Pengembangan Media Pembelajaran IPA dengan Animasi Macromedia Flash Berbasis Model Pengajaran Langsung (Direct Instruction) di Sekolah Dasar. Premiere Educandum : Jurnal Pendidikan Dasar Dan Pembelajaran, 5(02), 263-271. https: //doi.org/10.25273/pe.v5i02.289.

Maqfiroh, Khutobah, \& Budyawati. (2020). Pengembangan Media MOTIF (Monopoli Edukatif) dalam Pembelajaran Berbasis Multiple Intelligence. Cakrawala Dini: Jurnal Pendidikan Anak Usia Dini, 11(1), 64-74.

Nurseto, T. (2011). Membuat Media Pembelajaran yang Menarik. Jurnal Ekonomi Dan Pendidikan, 8(1), 20-21. https://doi.org/10.21831/jep.v8i1.706.

Nurul Husna1, S. A. S., \& Halim, A. (2017). Pengembangan Media Puzzle Materi Pencemaran Lingkungan. Jurnal Pendidikan Sains Indonesia (Indonesian Journal of Science Education), 5(1), 66-71. http://www.jurnal.unsyiah.ac.id/JPSI/article/view/8413/6802.

Pertiwi, I. N., Sumarno, \& Dwi, A. (2019). Pengaruh Model Make A Match Berbantu Media Kartu Bergambar terhadap Kemampuan Membaca dan Menulis. E-Journal PGSD Pendidikan Ganesha Mimbar PGSD, 7(3), 261-270. https://doi.org/10.23887/jjpgsd.v7i3.19412.

Purwantoko, Susilo, S. (2010). Kefektifan Pembelajaran dengan Menggunakan Media Puzzle terhadap Pemahaman IPA. Jurnal Pendidikan Fisika Indonesia, 6, 123-127.

Puspitasari, \& Murda. (2018). Pengaruh Model Pembelajaran IOC Berbantuan Media Audio Visual terhadap Hasil Belajar IPS. Mimbar PGSD Undiksha, 6(2). https: //doi.org/10.23887/jjpgsd.v6i2.19470.

Puspitorini, R., Prodjosantoso, A. K., Subali, B., \& Jumadi, J. (2014). Penggunaan Media Komik dalam Pembelajaran IPA untuk Meningkatkan Motivasi dan Hasil Belajar Kognitif dan Afektif. Jurnal Cakrawala Pendidikan, 3(3), 413-420. https://doi.org/10.21831/cp.v3i3.2385.

Putra, P. (2017). Pendekatan Etnopedagogi dalam Pembelajaran IPA SD / MI. Primary Education Journal (PEJ), 1(1), 17-23. http://pej.ftk.uinjambi.ac.id/index.php/PEJ/article/view/1.

Putri, D. K., Handayani, M., \& Akbar, Z. (2020). Pengaruh Media Pembelajaran dan Motivasi Diri terhadap Keterlibatan Orang Tua dalam Pendidikan Anak. Jurnal Obsesi : Jurnal Pendidikan Anak Usia Dini, 4(2), 649. https://doi.org/10.31004/obsesi.v4i2.418.

Raibowo, S., Nopiyanto, Y. E., \& Muna, M. K. (2019). Pemahaman Guru PJOK tentang Standar Kompetensi Profesional. Journal Of Sport Education (JOPE), 2(1), 10. https://doi.org/10.31258/jope.2.1.10-15.

Renda, N. T., \& Jampel, N. (2013). Penerapan Model Pembelajaran Team Assisted Individualization untuk Meningkatkan Kreativitas dan Hasil Belajar IPA Siswa Kelas IV. MIMBAR PGSD, 1(1).

Situmorang, M. A. (2012). Meningkatkan Kemampuan Memahami Wacana melalui Media Pembelajaran Puzzle. Jurnal Bahasa, 1(1), 1. https: //doi.org/10.24114/kjb.v1i1.146.

Sri Wahyuni. (2006). Mengembangkan Keterampilan Berpikir Kritis Siswa melalui Pembelajaran IPA Berbasis Problem-Based Learning. Program Studi Pendidikan Kimia PMIPA FKIP-UT, 23, 4.

Sudjana, N., \& Rivai, A. (2011). Media Pengajaran (Penggunaan \& Pembuatannya) (Sinar Baru). Bandung: Sinar Baru Aglesindo.

Sugiyono. (2014). Metode Penelitian Pendidikan. Alfabeta.

Syafitri, A., Amir, H., \& Elvinawati. (2019). Perbandingan Hasil Belajar Siswa Menggunakan Pembelajaran Kooperatif Tipe Team Games Tournament (TGT) dengan Media Ular Tangga dan Media Puzzle di Kelas XI. Jurnal Pendidikan Dan Ilmu Kimia, 3(2). https://doi.org/10.33369/atp.v3i2.9911.

Wahyuni, I. (2018). Pemilihan Media Pembelajaran. Jurnal Pendidikan, 1(1), 5.

Widayanti, N. M. A. G., Sudarma, I. K., \& Suarjana, I. M. (2020). Penerapan Model Make A Match Berbantuan Media Puzzle untuk Meningkatkan Hasil Belajar IPA Siswa Kelas V di SD. MIMBAR PGSD, 2(4), 331-342. https://doi.org/10.23887/jjpgsd.v4i1.7078.

Widiana, I. W. (2016). Pengembangan Asesmen Proyek Dalam Pembelajaran IPA di Sekolah Dasar. JPI (Jurnal Pendidikan Indonesia), 5(2), 147. https://doi.org/10.23887/jpi-undiksha.v5i2.8154.

Widiyatmoko, F. dan. (2014). Pengembangan Science Comic Berbasis Problem Based Learning sebagai Media Pembelajaran pada Tema Bunyi dan Pendengeran untuk Siswa SMP. Jurnal Pendidikan IPA Indonesia, 3(2). https://doi.org/10/15294/jpii.v3i2 .3114.

Widya Hastuti. (2017). Pengaruh Media Puzzle terhadap Hasil Belajar IPA Konsep Daur Hidup Makhluk Hidup Murid Kelas IV. Jurnal Penelitian Dan Penalaran, 4(1), 1.

Yektyastuti, R., \& Ikhsan, J. (2016). Pengembangan Media Pembelajaran Berbasis Android pada Materi Kelarutan untuk Meningkatkan Performa Akademik Peserta Didik SMA. Jurnal Inovasi Pendidikan IPA, 2(1), 88-99. https://doi.org/10.21831/jipi.v2i1.10289.

Zulfa, E., Nuroso, H., \& Reffiane, F. (2020). Keefektifan Model Pembelajaran Terpadu Tipe Sequenced Berbantu Media Puzzle terhadap Hasil Belajar Siswa. Jurnal Penelitian Dan Pengembangan Pendidikan, 4(1), 18-22. https://doi.org/10.23887/jppp.v4i1.24938. 